\title{
Status of POPs accumulation in the Yellow River Delta: From distribution to risk assessment
}

\author{
Jing $\mathrm{Li}^{1,2}$ Chunli Chen ${ }^{2} *$ Fadong $\mathrm{Li}^{1} *$ \\ 1 Key Laboratory of Ecosystem Network Observation and Modeling, Institute of Geographic Sciences \\ and Natural Resources Research, Chinese Academy of Sciences, Beijing 100101, China \\ 2 Key Laboratory of Poyang Lake Environment and Resource Utilization of MOE; School of \\ Environmental and Chemical Engineering, Nanchang University; Nanchang 330047, China
}

\section{* Joint corresponding authors:}

Chunli Chen, Key Laboratory of Poyang Lake Environment and Resource Utilization, Ministry of Education; School of Environmental and Chemical Engineering, Nanchang University; Nanchang 330047, China.E-mail: hnclchen@163.com

Fadong Li, Key Laboratory of Ecosystem Network Observation and Modeling, Institute of Geographic Sciences and Natural Resources Research, Chinese Academy of Sciences, Beijing 100101, China. Phone: 86-10-64889530; E-mail: lifadong@igsnrr.ac.cn 


\begin{abstract}
The Yellow River Delta (YRD) is a large region of China with complex pollution sources and a long history of environmental deterioration. Despite this, relatively little data exists on the status of important contaminants of concern in this region. Here, we review the literature on the status of key persistent organic pollutants (POPs) of concern including organochlorine pesticides (OCPs), polycyclic aromatic hydrocarbons (PAHs), and polychlorinated biphenyls (PCBs) in the YRD. Sources, source identification methods, and spatial distribution patterns are presented. Additionally, POPs contamination levels reported in the literature were evaluated against popular regulatory limits worldwide to form a basis for overall environmental health. Our review determined that OCPs in the YRD originated mainly from current pesticide use and past agricultural pesticide application. Sources of PAHs included petrochemical inputs, coal fired plants, and wood combustion. PCB levels were impacted by the petrochemical industry as well as waste disposal of PCB containing equipment. OCPs exhibited a spatial distribution pattern that increased along the urban-rural gradient, while the opposite was seen for PAHs and PCBs. Comparisons of POPs contamination levels in the YRD with popular regulatory limits suggest that the extent of PCB contamination all mediums (sediment, soil, water, and biota) exceeded that of PAHs and OCPs. Overall pollution levels in the YRD seem to be in control; however, levels from heavily polluted point sources raise numerous concerns about the ecological health of the region and require more attention from regulatory authorities.
\end{abstract}

\title{
Keyword
}

POPs; Environmental occurrence; Risk assessment; Origins; Yellow River esturry; Oil field 
The Yellow River Delta (YRD) is a typical ecotone of the Yellow River and Bohai Bay (Xie et al. 2012) suffering from enormous environmental deterioration from industrialization. With an area of $2200 \mathrm{~km}^{2}$, the watershed of the YRD is the largest and youngest wetland in the warm temperate zone of China (Yuan et al. 2012), and is also the youngest land in the world. Extremely high sediment loads (>1000 million tons per year, $\mathrm{Mt} / \mathrm{yr}$ ) have been discharged to the sea over thousands of years as a result of poor agricultural practices in the Loess region (Oliva et al. 2015). High sediment loading from the river and transport by hyperpycnal flows into the estuary have made considerable contributions to the deltaic depositional system (Fan et al. 2009). In the environment, persistent organic pollutants (POPs) tend to adsorb to organic matter due to their chemical properties. Once they enter aquatic environments, they preferentially sorb to organic particles and are deposited in sediments. Thus, large quantities of organic pollutants enter the Yellow river through this sediment loading(Yang et al. 2009). In China, dichlorodiphenyltrichloroethane (DDT) and hexachlorocyclohexane $(\mathrm{HCH})$ were the most widely used and produced organochlorine pesticides (OCPs). These OCPs were produced for use in agriculture, forestry, and public health for more than four decades (Cai et al. 2008).

Due to their bioaccumulation potential, persistence, toxicity and long-range environmental transport ability, POPs are of great concern to scientists, environmental quality managers and policy makers (IPCS 2000; Keita-Ouane et al. 2001; UNEP 2003; Peterson et al. 2010). Measurement of their concentrations and evaluation of ecological risk in a large-scale region is of significant importance to protect environmental health (Sudaryanto et al. 2011). A large amount of work has been carried out regarding state of POPs globally. The United Nations Environment Programme (UNEP) (UNEP 2003), International Programme on Chemical Safety (IPCS) (IPCS 2000), Intergovernmental Forum on Chemical Safety (IFCS) (Peterson et al. 2010), Inter-Organization Programme for the Sound Management of Chemicals (IOMC) (Keita-Ouane et al. 2001) and other international organizations are actively involved in the research of characteristics, hazards, fate, etc. of POPs.

With the rapid economic development in China over the last few decades, environmental pollution caused by POPs has been identified in several delta areas, e.g., the Mekong Delta (Cenci and Martin 2004), the Pearl River Delta (Yang et al. 2007), and the Yangtze River Delta (Yang et al. 2009). Most investigations of pollutants in the YRD have focused on three main POPs of 
concern: OCPs, polycyclic aromatic hydrocarbons (PAHs) and polychlorinated biphenyls (PCBs)

(Fan et al. 2009; Hu et al. 2010; Liu et al. 2010). It is important to note that the Shengli Oil Field, the second largest oilfield in China, is located in the YRD. Given the scale of mining and oil refining activities occurring here, it is of significance to assess the ecological risk of petroleum contaminants in this area. A comprehensive investigation of the distributions of POPs in the YRD will be useful to determine the sources, evaluate ecological risks, and create remediation strategies.

This review is organized as follows: Firstly, previous usage of POPs and potential pollution sources in the YRD are described. Secondly, environment occurrence is introduced on a matrix-specific basis, i.e., soil, sediment, water, and organisms. Thirdly, environmental sources are identified mainly focusing on historical agriculture usage, technical production, atmospheric deposition, and riverine transport. Finally, potential environmental effects are examined through comparisons between environmental quality guidelines and levels of POPs in environmental matrices.
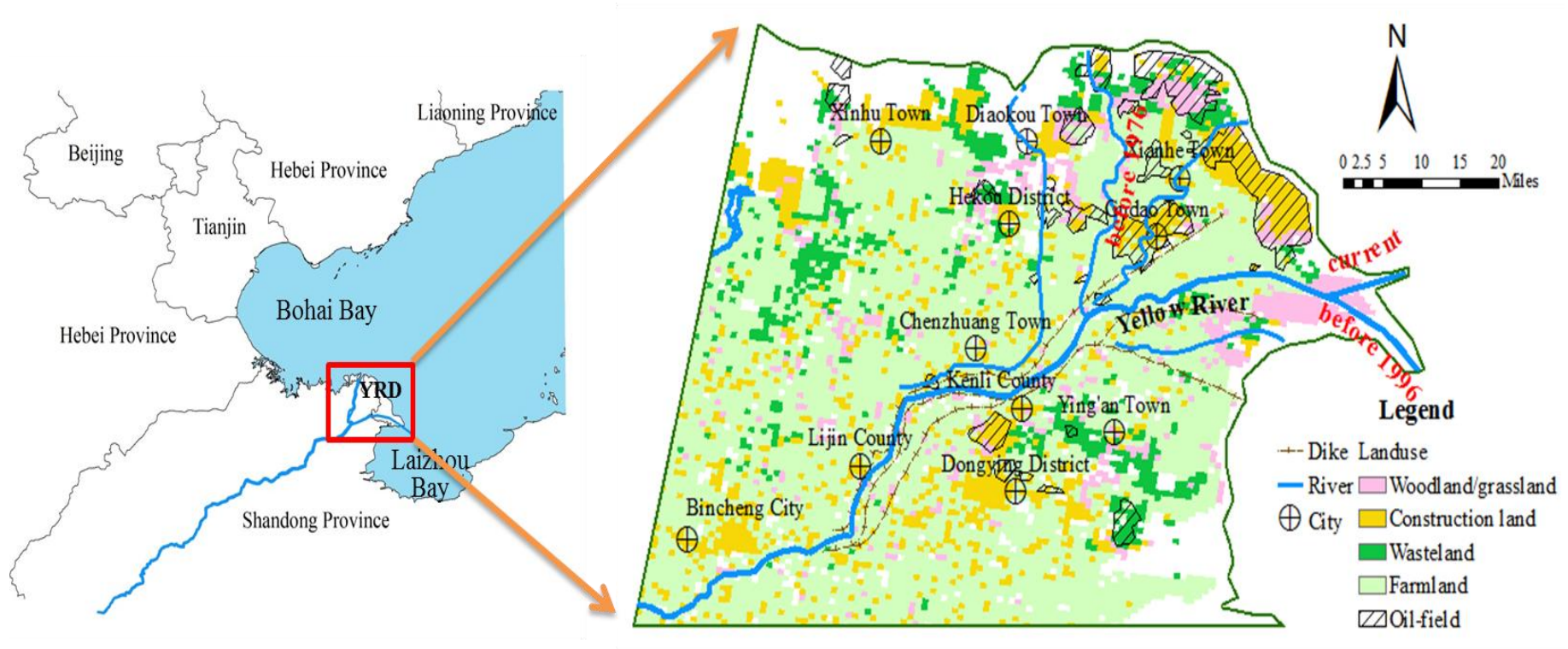

Fig.1 The location of YRD and the shifting history of the Yellow River

The YRD is a rapidly developing petrochemical and agricultural area of China with a long history of pollution and complex sources of contamination (Fig. 1). From 1960 to 1990, large amounts of lindane, dicofol, and technical DDT in China were produced as well as widely used for pest control. It has been estimated that approximately 258, 000 tons of $\mathrm{HCH}$ and DDT were used in China in 1990, accounting for $74.0 \%$ of all pesticide use (Tao et al. 2007). Agricultural usage of HCHs and DDTs lasted from 1953 to 1993 in the YRD (Tao et al. 2006). 
PAH contamination is derived from petroleum sources (i.e., petrogenic sources) and from incomplete combustion of carbonaceous materials (i.e., pyrogenic sources). These sources occur naturally and as a result of human activities (Edwards 1983). Cracking and refining of petroleum and incomplete combustion of fossil fuels are known to produce large amounts of PAHs (Xie et al. 2012). Crude oil cracking sites, oil wells, and petrochemical industrial activities are point sources of PAHs, which can increase regional levels of PAH contamination through short-range and long-range transport (Wilcke 2007). The Shengli Oilfield is arguably the largest point source of PAH contamination in the YRD. Oil well blowouts, leaks and spills from underground tanks, pipelines and illegal disposal threaten the ecosystem in this area. Manufacturers in the YRD have by-produced PAHs (Hu et al. 2005). Effluents from several production facilities were treated ineffectively and wastewater discharged from these facilities contributed large amounts of PAH contamination (Li et al. 2006). Sewage irrigation was used at a very large scale in this area for over 30 years because of the shortage of water resources (Gong et al. 2004).

PCBs have a long history of extensive production and use in China. It has been estimated that 10,000 tons of PCB 3 (9000 t) and PCB 5 (1000 t) were produced in China from 1965 to 1974 (Xing et al. 2005). PCB 3 was used primarily in power capacitors applied in electricity production, distribution and transmission, and PCB 5 was used mainly as a paint additive in China (China SEPA 2003). Furthermore, following the ban on the production and use of PCBs, most of the outdated PCB-containing equipment (equipment filled with PCBs as dielectric fluid) was removed from use and stored. Potential POPs pollution sources at YRD are listed in Table 1.

Table 1 Previous usage of POPs and potential pollution sources in the study area ${ }^{\text {a }}$

\begin{tabular}{|c|c|c|}
\hline Pollutants(group) & $\begin{array}{l}\text { Potential emission/pollution } \\
\text { sources/Usage in China }\end{array}$ & $\begin{array}{l}\text { Potential emission sources } \\
\text { in the YRD }\end{array}$ \\
\hline $\begin{array}{l}\mathrm{HCH}: \\
\text { Technical } \mathrm{HCH} \text { and } \\
\text { Lindane }\end{array}$ & $\begin{array}{l}\text { Mainly used in agriculture, pest control } \\
\text { in rice, wheat, soybean, maize, cotton, } \\
\text { sorghum and orchard; } \\
\text { a small apportion was also used in } \\
\text { forestry and public health; }\end{array}$ & $\begin{array}{l}\text { Extensive application in } \\
\text { agriculture and forestry; } \\
\text { Wastewater irrigation; } \\
\text { Major use on wheat land }\end{array}$ \\
\hline $\begin{array}{l}\text { DDT } \\
\text { and its metabolites: } \\
\text { Technical DDT }\end{array}$ & $\begin{array}{l}\text { Disease vector; } \\
\text { intermediate of dicofol production; } \\
\text { antifouling paint for ships; } \\
\text { Export for controlling malaria; } \\
\text { Insecticide in orchards, paddy fields and }\end{array}$ & $\begin{array}{l}\text { Extensive application in } \\
\text { agriculture and forestry; } \\
\text { Transportation leakage; } \\
\text { Wastewater irrigation; } \\
\text { Waste product dumps; }\end{array}$ \\
\hline
\end{tabular}


vegetable fields(until 1983);

mosquito-repellent incense(until 2002);

Acaricide in agriculture

(apple, orange and cotton)

Dicofol

(10\%DDT impurities)

\begin{tabular}{|c|c|c|}
\hline PCB & $\begin{array}{l}\text { 10,000 tons of PCBs were produced } \\
\text { from } 1965 \text { to 1974; Power capacitors; } \\
\text { Paint additive; Heat exchangers; } \\
\text { Hydraulic systems, Carbonless copy } \\
\text { paper; Industrial oils; Additives; Flame } \\
\text { retardants and other }\end{array}$ & $\begin{array}{l}\text { Power capacitors; Paint additive; } \\
\text { Water runoff (non- point source) } \\
\text { from the industrial production and } \\
\text { use by the enterprises along the } \\
\text { Yellow River; } \\
\text { PCB waste storage; } \\
\text { Oilfield drilling activities; }\end{array}$ \\
\hline PAH & $\begin{array}{l}\text { Petroleum sources (i.e., petrogenic } \\
\text { sources) and from incomplete } \\
\text { combustion of carbonaceous materials } \\
\text { (i.e., pyrogenic sources) }\end{array}$ & $\begin{array}{l}\text { By-product of crude oil, oil wells, } \\
\text { and petrochemical industrial } \\
\text { activities; } \\
\text { Oil well blowouts, leaks and spills } \\
\text { from underground tanks; } \\
\text { Pipelines and illegal disposal; } \\
\text { Manufacturers; Sewage irrigation; }\end{array}$ \\
\hline
\end{tabular}

${ }^{\text {a }}$ Sources: (China SEPA 2003; Gong et al. 2004; Hu et al. 2005; Li et al. 2006; Tao et al. 2006; Tao et al. 2007; Wilcke 2007; Wang et al. 2009).

Soil is the largest sink in the environment and significantly influences human and environmental health. In China, OCPs, PAHs and PCBs were the most frequently studied POPs in soil (Xing et al. 2005), and concentrations of POPs in soil have been increasing for 100-150 years, especially in urban areas (Cai et al. 2008). In the YRD, more than 400 soil samples collected from different cities and regions have been analyzed for the occurrence of OCPs, PAHs and PCBs.

Soil OCPs have been investigated in at least 10 studies. DDTs ( $p, p^{\prime}$ - DDT, $o, p^{\prime}$ - DDT, $p$, $p^{\prime}$ - DDE, $o, p^{\prime}$ - DDE, $p, p^{\prime}$ - DDD, $o, p^{\prime}$ - DDD) and HCHs $(\alpha-\mathrm{HCH}, \beta-\mathrm{HCH}, \gamma-\mathrm{HCH}, \delta$ - HCH) were the main contributors. Occurrences of OCPs in soil in various parts of YRD are described in Table 2 (all concentrations are normalized to dry sample weight). Concentrations of DDTs ranged from $0.05-3819 \mathrm{ng} / \mathrm{g}$ (Fig. 2). Spatial distribution varied greatly and rendered a clear upward trend along the urban-rural gradient (Chen et al. 2011; Xie et al. 2012). DDT concentrations in rural areas varied between 4.10-3818.76 ng/g (with a mean of $315.65 \mathrm{ng} / \mathrm{g}$ ), whilst that in the city varied from 3.34-533.53 ng/g (with a mean of $63.81 \mathrm{ng} / \mathrm{g}$ ) (Chen et al. 2011; Yuan et al. 2011). Among DDTs, the predominant compound was $p, p^{\prime}$-DDE, which accounted for $63.0 \%-82.7 \%$ of the DDT concentration, followed by $p, p^{\prime}$-DDT, and lastly was $p, p^{\prime}$-DDD. 
The distribution pattern of DDTs varied among urban, suburban, and rural areas. Along an urban-rural gradient, the $o, p^{\prime}$-DDTs ( $o, p^{\prime}$-DDT, $o, p^{\prime}$-DDE, and $o, p^{\prime}$-DDD) percentages declined significantly, from $38.3 \%$ to $4.3 \%$ (Xie et al. 2012). One possible explanation is that after the ban of DDT for agricultural production, chemicals containing $o, p^{\prime}$-DDT, such as dicofol, contributed more to DDT pollution in urban and suburban areas than in rural areas.

The Yellow River was artificially diverted from the Old Course to the Modern Course in 1976 (Fig. 1). After the Yellow River diversion, more than $450 \mathrm{~km}^{2}$ new land was made in the Yellow River estuary with the sediment deposition speed of $13 \mathrm{~km}^{2} /$ year. At the same time, a series of ecological problems occurred in the Old Course of the Yellow River, including the shrinkage of wetlands, deterioration of water quality, water and soil erosion, and decreased agricultural activities. The area between the Old Course and the Modern Course built up the Middle Area. Concentrations of soil OCPs in Modern Course, Middle Area and the Old Course of the Yellow River were 1.4-39.9, 2.9-22.7, 3.7-36.1 ng/g (Zhang 2011). A comparison of DDTs concentrations among the Modern Course, Middle Area and the Old Course of the Yellow River was in the order of Old Course > Modern Course > Middle Area, with the mean values were 3.28, 1.23 and $1.15 \mathrm{ng} / \mathrm{g}$, respectively (Zhang 2011). Concentrations of HCHs ranged from 0.01-18.5 ng/g (with a mean of $3.34 \mathrm{ng} / \mathrm{g}$ ), and showed the trend of Modern Course > Old Course > Middle Area. Due to its low volatility, high stability and poor biodegradability, $\beta$ - $\mathrm{HCH}$ was the most stable isomer of $\mathrm{HCH}$ residues, accounting for $46 \%$ of the total $\mathrm{HCH}$ content. Other $\mathrm{HCH}$ isomers showed the trend of $\beta-\mathrm{HCH}>\delta-\mathrm{HCH}>\alpha-\mathrm{HCH}>\gamma-\mathrm{HCH}$ in most measured soils (Zhang 2011). 


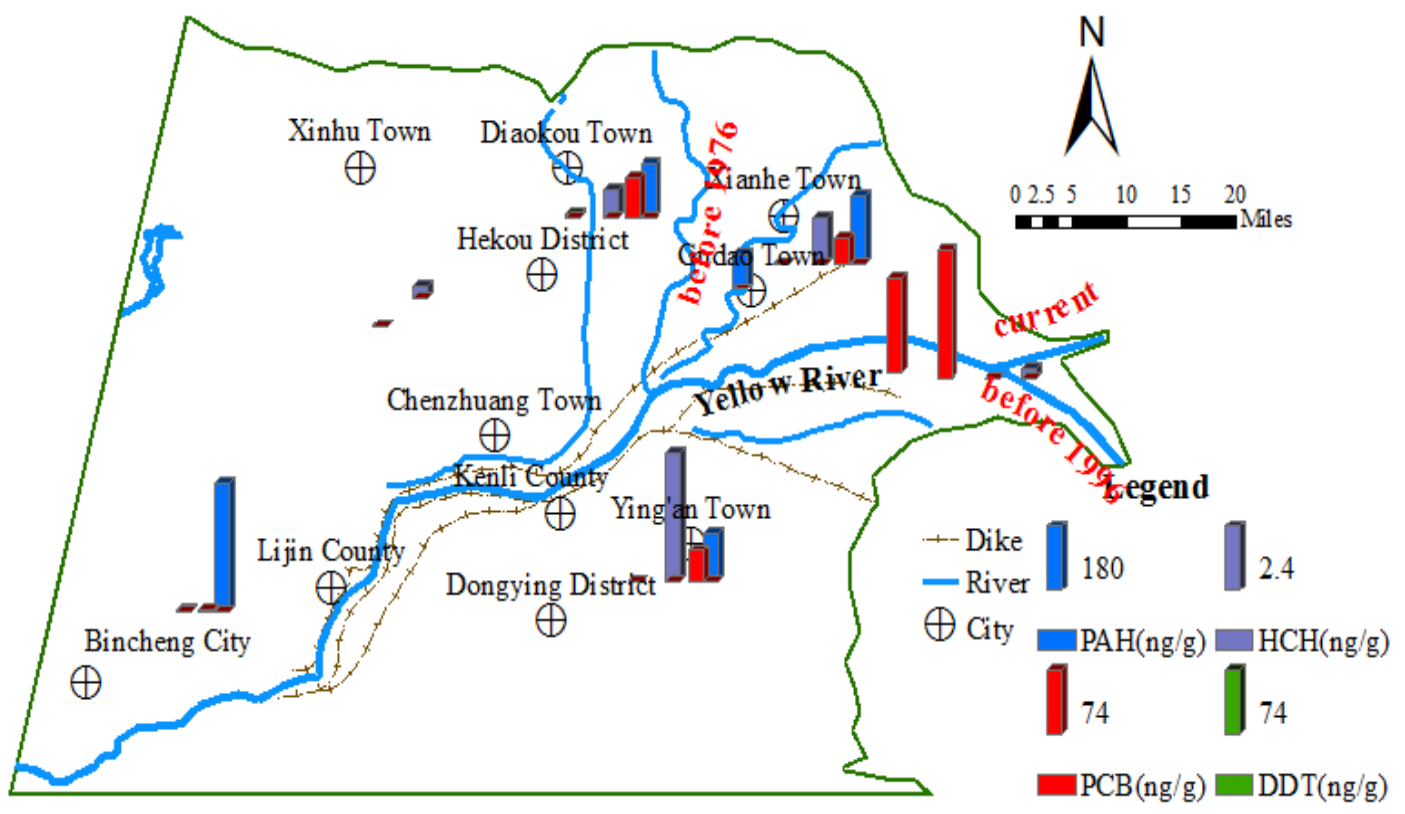

Fig.2 The spatial distribution of soil POPs in the YRD

(Data are from references of Tao, 2008; Fan et al., 2009; Liu et al., 2010; Chen et al., 2011; Zhang, 2011; Xie et al., 2012a; Xie et al., 2012b; Yuan et al., 2012; Da et al., 2014)

PCBs generally enter the air, soil, water and sediment during their manufacture and use (Wong and Poon, 2003). Few studies have surveyed PCB contamination in soil, and when undertaken, the focus was on already heavily polluted areas in China (Xing et al. 2005). Measured soil concentrations of PCBs in the YRD ranged from non-detectable to $124.2 \mathrm{ng} / \mathrm{g}$ and were dominated by heavily chlorinated PCBs (PCB-101 and PCB-118) (Zhang 2011). Soil PCBs concentrations were significantly greater in urban than suburban or rural areas (Xie et al. 2012). The mean concentration of PCBs in the urban area was $6.3 \mathrm{ng} / \mathrm{g}$, whilst that in the suburban and rural area was $1.9 \mathrm{ng} / \mathrm{g}$ and $1.6 \mathrm{ng} / \mathrm{g}$, respectively. The production of PCBs was stopped in 1980s in China, four years after Yellow River was diverted into the two courses. The spatial pattern of soil PCBs showed the trend of Old Course > Modern Course > Middle Area. Cconcentrations ranged from 15.6-124.2 ng/g, 9.3-65.4 ng/g and 19.0-73.8 ng/g, with mean value of 45.0, 35.7 and $29.5 \mathrm{ng} / \mathrm{g}$, respectively (Zhang 2011). In general, low-chlorinated PCBs (such as PCB 28 and PCB 52) were more concentrated in the Modern Course while heavily chlorinated PCBs such as PCB 180 and PCB 138, among others, were more concentrated in the Old Course.

Concentrations of 16 PAHs listed for priority control by the USEPA have been measured in soil in the YRD. Concentrations varied over the range of 25.5 to $2176.0 \mathrm{ng} / \mathrm{g}$, with an average concentration of $229.8 \mathrm{ng} / \mathrm{g}$. Concentrations significantly increased along the rural-urban gradient 
$(P<0.05)$ (Tao 2008; Xie et al. 2012). Average PAH concentrations in the rural and suburban areas were $278.7 \mathrm{ng} / \mathrm{g}$ and $284.6 \mathrm{ng} / \mathrm{g}$, respectively, far exceeding naturally occurring background levels of a typical indigenous soil that result from plant synthesis and natural fires (Tao 2008). PAHs are compounds composed of one or more benzene rings with varying degrees of persistence, toxicity, and mutagenicity based on molecular weight of the compound. Environmentally significant PAHs are those with two to seven benzene rings. Low molecular weight PAHs (2-4 rings) tend to be more acutely toxic, while high molecular weight are not, (though have other deleterious effects). The relative proportion of two to six ringed PAHs in the YRD ranged from $6.75 \%$ to $40.84 \%$. Four-ringed PAHs made up the largest relative proportion of soil PAHs and two-ringed PAH made up the smallest proportion. Generally speaking, PAHs with more rings accounted for a dominant proportion of soil PAHs (Cao et al. 2012). 
Table 2 Concentrations of DDT, HCH, PCB and PAH in soil, sediment, and organisms

\begin{tabular}{|c|c|c|c|c|c|c|c|}
\hline & Location & Time & Depth & $\begin{array}{l}\text { Compo } \\
\text { sition }\end{array}$ & Concentration & Source & Reference \\
\hline \multirow[t]{13}{*}{ Soil } & DDT & & & & & & \\
\hline & $\begin{array}{l}\text { Two sides of modern and old } \\
\text { course of the Yellow River, and } \\
\text { Shen Xiangou basin }\end{array}$ & $\begin{array}{l}2007.5- \\
2008.5\end{array}$ & $0-5 \mathrm{~cm}$ & 4 & $\begin{array}{l}0.05-6 \mathrm{ng} / \mathrm{g}(0.85 \\
\mathrm{ng} / \mathrm{g})\end{array}$ & $\begin{array}{l}\text { Pesticides residues in the soil and new input } \\
\text { from pesticide }\end{array}$ & (Yuan et al. 2012) \\
\hline & $\begin{array}{l}\text { Bincheng District in the Binzhou } \\
\text { City }\end{array}$ & 2009.9 & $0-20 \mathrm{~cm}$ & 6 & $\begin{array}{l}63.8-315.6 \mathrm{ng} / \mathrm{g} \\
(190.5 \mathrm{ng} / \mathrm{g})\end{array}$ & Past DDT usage and dicfol application & (Chen et al. 2011) \\
\hline & $\begin{array}{l}\text { Bincheng District in the Binzhou } \\
\text { City }\end{array}$ & 2009.9 & $0-15 \mathrm{~cm}$ & 6 & $3.3-3819 \mathrm{ng} / \mathrm{g}$ & $\begin{array}{l}\text { Past DDT usage ( } 86.4 \%) \text { and dicofol }(13.6 \%) \\
\text { application }\end{array}$ & (Xie et al. 2012) \\
\hline & $\begin{array}{l}\text { Modern Course of the Yellow } \\
\text { River }\end{array}$ & 2008.8 & $0-15 \mathrm{~cm}$ & 4 & $1.23 \mathrm{ng} / \mathrm{g}$ & $\begin{array}{l}\text { Agriculture usage and dicofol application, } \\
\text { water and sediment transport and atmospheric } \\
\text { deposition }\end{array}$ & (Zhang 2011) \\
\hline & Middle Area of the Yellow River & 2008.8 & $0-15 \mathrm{~cm}$ & 4 & $1.15 \mathrm{ng} / \mathrm{g}$ & $\begin{array}{l}\text { Agriculture usage, water and sediment } \\
\text { transport and atmospheric deposition }\end{array}$ & (Zhang 2011) \\
\hline & Old Course of the Yellow River & 2008.8 & $0-15 \mathrm{~cm}$ & 4 & $3.28 \mathrm{ng} / \mathrm{g}$ & History agriculture usage before 1976 & (Zhang 2011) \\
\hline & $\begin{array}{l}\text { Nature Reserve of the Yellow } \\
\text { River Delta }\end{array}$ & 2012.7 & $0.20 \mathrm{~cm}$ & 4 & $0.17-10.46 \mathrm{ng} / \mathrm{g}$ & Long-term weathering of DDTs & (Da et al. 2014) \\
\hline & HCH & & & & & & \\
\hline & $\begin{array}{l}\text { Two sides of modern and old } \\
\text { course of the Yellow River, and } \\
\text { Shen Xiangou basin }\end{array}$ & $\begin{array}{l}2007.5 \\
2008.5\end{array}$ & $0-5 \mathrm{~cm}$ & 4 & $\begin{array}{l}0.04-1.19 \mathrm{ng} / \mathrm{g} \\
(0.47 \mathrm{ng} / \mathrm{g})\end{array}$ & $\begin{array}{l}\text { Pesticides residues in the soil and new input } \\
\text { from pesticide }\end{array}$ & (Yuan et al. 2012) \\
\hline & $\begin{array}{l}\text { Modern Course of the Yellow } \\
\text { River }\end{array}$ & 2008.8 & $0-15 \mathrm{~cm}$ & 4 & $4.75 \mathrm{ng} / \mathrm{g}$ & $\begin{array}{l}\text { Technical production, Pesticide residues, } \\
\text { water and sediment transport and atmospheric } \\
\text { deposition }\end{array}$ & (Zhang 2011) \\
\hline & Middle Area of the Yellow River & 2008.8 & $0-15 \mathrm{~cm}$ & 4 & $1.68 \mathrm{ng} / \mathrm{g}$ & $\begin{array}{l}\text { Pesticide residues, water and sediment } \\
\text { transport and atmospheric deposition }\end{array}$ & (Zhang 2011) \\
\hline & Old Course of the Yellow River & 2008.8 & $0-15 \mathrm{~cm}$ & 4 & $1.03 \mathrm{ng} / \mathrm{g}$ & Pesticide residues, water and sediment & (Zhang 2011) \\
\hline
\end{tabular}




\begin{tabular}{|c|c|c|c|c|c|c|c|}
\hline & & & & & & transport and atmospheric deposition & \\
\hline & $\begin{array}{l}\text { Nature Reserve of the Yellow } \\
\text { River Delta }\end{array}$ & 2012.7 & $0.20 \mathrm{~cm}$ & 4 & $0.28-1.32 \mathrm{ng} / \mathrm{g}$ & $\begin{array}{l}\text { Historical sources and small amount of } \\
\text { lindane }\end{array}$ & (Da et al. 2014) \\
\hline & PCB & & & & & & \\
\hline & $\begin{array}{l}\text { Bincheng District in the Binzhou } \\
\text { City }\end{array}$ & 2009.9 & $0-20 \mathrm{~cm}$ & 7 & $0-87 \mathrm{ng} / \mathrm{g}$ & $\begin{array}{l}\text { Petrochemical industry }(77.1 \%) \text {, municipal } \\
\text { waste disposal }(16.5 \%) \text {, }\end{array}$ & (Xie et al. 2012) \\
\hline & $\begin{array}{l}\text { Modern Course of the Yellow } \\
\text { River }\end{array}$ & 2008.8 & $0-15 \mathrm{~cm}$ & 9 & $\begin{array}{l}9.3-65.4 \mathrm{ng} / \mathrm{g} \\
(35.7 \mathrm{ng} / \mathrm{g})\end{array}$ & $\begin{array}{l}\text { Waste capacitors and transformers' leakage, } \\
\text { new input with sediment }\end{array}$ & (Zhang 2011) \\
\hline & Middle Area of the Yellow River & 2008.8 & $0-15 \mathrm{~cm}$ & 9 & $\begin{array}{l}19.0-73.8 \mathrm{ng} / \mathrm{g} \\
(29.5 \mathrm{ng} / \mathrm{g})\end{array}$ & Waste capacitors and transformers' leakage & (Zhang 2011) \\
\hline & Old Course of the Yellow River & 2008.8 & $0-15 \mathrm{~cm}$ & 9 & $\begin{array}{l}15.6-124.2 \mathrm{ng} / \mathrm{g} \\
(45 \mathrm{ng} / \mathrm{g})\end{array}$ & History production and usage before 1976 & (Zhang 2011) \\
\hline & Modern Yellow River Delta & 2010 & $0-20 \mathrm{~cm}$ & 12 & $108.7-2152.7 \mathrm{ng} / \mathrm{kg}$ & $\begin{array}{l}\text { Water runoff }(49.6 \%) \text {, point sources }(25.1 \%) \text {, } \\
\text { and atmospheric precipitation }(8.4 \%)\end{array}$ & (Liu et al. 2010) \\
\hline & Modern YRD & 2006.10 & $0-10 \mathrm{~cm}$ & 12 & $\begin{array}{l}147.75-505.58 \\
\mathrm{ng} / \mathrm{kg}\end{array}$ & - & (Fan et al. 2009) \\
\hline & PAH & & & & & & \\
\hline & $\begin{array}{l}\text { East of the Hekou district, north } \\
\text { shore of the Yellow River estuary }\end{array}$ & & $0-20 \mathrm{~cm}$ & 15 & $\begin{array}{l}25.53-202.78 \mathrm{ng} / \mathrm{g} \\
(99.38 \mathrm{ng} / \mathrm{g})\end{array}$ & Mixed source of petrogenic and pyrogenic & (Tao 2008) \\
\hline & $\begin{array}{l}\text { Modern Course of the Yellow } \\
\text { River }\end{array}$ & 2008.8 & $0-15 \mathrm{~cm}$ & 16 & $\begin{array}{l}122.2-148.2 \mathrm{ng} / \mathrm{g} \\
(133.2 \mathrm{ng} / \mathrm{g})\end{array}$ & $\begin{array}{l}\text { Mixed source of coal, wood and oil } \\
\text { combustion }\end{array}$ & (Zhang 2011) \\
\hline & Middle Area of the Yellow River & 2008.8 & $0-15 \mathrm{~cm}$ & 16 & $\begin{array}{l}153.0-228.9 \mathrm{ng} / \mathrm{g}, \\
(192.1 \mathrm{ng} / \mathrm{g})\end{array}$ & - & (Zhang 2011) \\
\hline & Old Course of the Yellow River & 2008.8 & $0-15 \mathrm{~cm}$ & 16 & $\begin{array}{l}126.5-198.9 \mathrm{ng} / \mathrm{g} \\
(148.7 \mathrm{ng} / \mathrm{g})\end{array}$ & - & (Zhang 2011) \\
\hline & $\begin{array}{l}\text { Bincheng District in the Binzhou } \\
\text { City }\end{array}$ & 2009.9 & $0-15 \mathrm{~cm}$ & 16 & $\begin{array}{l}181.1-2176.0 \mathrm{ng} / \mathrm{g} \\
(359.8 \mathrm{ng} / \mathrm{g})\end{array}$ & $\begin{array}{l}\text { Petroleum inputs for the urban and suburban } \\
\text { areas, and biomass burning for the rural }\end{array}$ & (Xie et al. 2012) \\
\hline Sediment & DDT & & & & & & \\
\hline
\end{tabular}




\begin{tabular}{|c|c|c|c|c|c|c|c|}
\hline & $\begin{array}{l}\text { Lower stream of Yellow River and } \\
\text { its tributary }\end{array}$ & 2005.11 & $\begin{array}{l}\text { surface } \\
\text { sediment }\end{array}$ & 4 & $0.09-12.88 \mathrm{ng} / \mathrm{g}$ & - & (Sun et al. 2008) \\
\hline & Old Yellow River Estuary & 2012.7 & $\begin{array}{l}\text { surface } \\
\text { sediment }\end{array}$ & & $0.04-1.07 \mathrm{ng} / \mathrm{g}$ & Historical residue & (Da et al. 2014) \\
\hline & \multicolumn{7}{|l|}{ HCH } \\
\hline & $\begin{array}{l}\text { Lower stream of Yellow River and } \\
\text { its tributary }\end{array}$ & 2005.11 & $\begin{array}{l}\text { surface } \\
\text { sediment }\end{array}$ & 4 & $0.05-5.03 \mathrm{ng} / \mathrm{g}$ & - & (Sun et al. 2008) \\
\hline & Old Yellow River Estuary & 2012.7 & $\begin{array}{l}\text { surface } \\
\text { sediment }\end{array}$ & 4 & $0.00-14.85 \mathrm{ng} / \mathrm{g}$ & $\begin{array}{l}\text { The technical historical residue and recent } \\
\text { lindane }\end{array}$ & (Da et al. 2014) \\
\hline & \multicolumn{6}{|l|}{ РАН } & \\
\hline & Yellow River Estuary & 2006.8 & & 25 & $\begin{array}{l}48.56-277.12 \mathrm{ng} / \mathrm{g}, \\
(122.92 \mathrm{ng} / \mathrm{g})\end{array}$ & $\begin{array}{l}\text { Oil spill }(74.5 \%) \text {, vehicles emission and } \\
\text { natural gas burning }(12.8 \%) \text { and coking } \\
\text { combustion }(12.7 \%)\end{array}$ & (Liu 2008) \\
\hline & Southern YRD & 2007.5 & $\begin{array}{l}\text { surface } \\
\text { sediment }\end{array}$ & 16 & $\begin{array}{l}70.58-826.12 \mathrm{ng} / \mathrm{g} \\
(458.5 \mathrm{ng} / \mathrm{g})\end{array}$ & Oil source, mainly caused by petroleum & (Yuan et al. 2011) \\
\hline & Northern YRD & 2007.5 & $\begin{array}{l}\text { surface } \\
\text { sediment }\end{array}$ & 16 & $\begin{array}{l}27.43-128.97 \mathrm{ng} / \mathrm{g} \\
(71.096 \mathrm{ng} / \mathrm{g})\end{array}$ & Anthropogenically induced & (Yuan et al. 2008) \\
\hline & $\begin{array}{l}\text { Yellow River Estuary and it's } \\
\text { adjacent areas }\end{array}$ & 2003.9 & & 16 & $371-650 \mathrm{ng} / \mathrm{g}$ & Oil pollution and combustion of fossil fuels & (Zhang 2008) \\
\hline & $\begin{array}{l}\text { Yellow River Estuary and it's } \\
\text { adjacent areas }\end{array}$ & 2007.8 & & 16 & $111.3-204.8 \mathrm{ng} / \mathrm{g}$ & $\begin{array}{l}\text { Pyrogenic origin for the north and middle } \\
\text { area, petrogenic and pyrogenic sources for } \\
\text { the northwest }\end{array}$ & (Hu et al. 2010) \\
\hline & Yellow River Estuary & 2006.8 & & 15 & $\begin{array}{l}47.4-202.6 \mathrm{ng} / \mathrm{g} \\
(101.6 \mathrm{ng} / \mathrm{g})\end{array}$ & $\begin{array}{l}\text { Coal-fired }(30.5 \%), \quad \text { wood } \\
(27.7 \%), \text { gasoline } \quad(17.5 \%) \text { and diesel } \\
\text { combustion }(12.53 \%)\end{array}$ & (Liu et al. 2009) \\
\hline \multirow[t]{2}{*}{ Organisms } & \multicolumn{6}{|l|}{ DL-PCB } & \\
\hline & Modern YRD & 2006.10 & $\begin{array}{l}\text { five plant } \\
\text { species }\end{array}$ & 12 & $2.32-287.60 \mathrm{ng} / \mathrm{kg}$ & Not from the soil but the air & (Fan et al. 2009) \\
\hline
\end{tabular}


There were only two studies related to OCPs residues in the surface sediments from the YRD (Sun et al., 2008; Da et al., 2014b). OCPs in twenty-three surface sediment samples from the middle and lower reaches of the Yellow River were analyzed. Correlations between OCP concentrations, the granularity of sediments, and total organic content (TOC) were discussed along with correlations among various components of the OCPs.. OCP concentrations in sediment samples were in the range of 0.35-22.92 ng/g. Concentrations of HCHs and DDTs varied over 0.001-14.85 $\mathrm{ng} / \mathrm{g}$ and $0.04-12.88 \mathrm{ng} / \mathrm{g}$, respectively. Contamination levels of OCPs in sediment increased from the middle to the lower reaches along the Yellow River (Sun et al., 2008). Strong correlations were found between the OCPs and clay particles percent (correlation coefficients $r=0.89, p<0.01$ ), TOC $(r=0.79, p<0.01)$, hexachlorobenzene $(r=0.88, p<0.01)$, HCHs $(r=0.95, p<0.01)$, nonachlor $(r=0.87$, $p<0.01)$, B-endosulfan $(r=0.94, p<0.01)$ in sediments.

These correlations played an important role in determining the level of OCPs in the sediment. Correlations between HCHs and each of hexachlorobenzene $(r=0.80, p<0.01)$, trans-chlordane $(r=0.99, p<0.01)$, endosulfan pesticides $(r=0.75, p<0.01)$ were also strong. These results indicated that the OCPs possibly have the same or similar sources and distribution mechanisms. The values of $\alpha / \gamma-\mathrm{HCH}$ in sediment were in the range of $0-6.4$, and the ratio of (DDE+DDD)/DDTs in the sediment core ranged from 0-0.87 (Da et al., 2014b). Based on these ratio, $\mathrm{HCHs}$ contamination resulted from recent use of lindane. DDTs in this area were mainly due to residues from historical use in the region.

Occurrence of sediment PAHs in the wetland, riverine, estuarine environments and adjacent areas has been widely investigated (Table 2). In the sediments of Yellow River estuary, concentrations of sixteen PAHs varied from $27.43 \mathrm{ng} / \mathrm{g}$ to $1826.12 \mathrm{ng} / \mathrm{g}$ (average concentrations were from 71.093 to $458.5 \mathrm{ng} / \mathrm{g}$ ) (Yuan et al. 2008; Chen et al. 2011; Yuan et al. 2011). Nap and Phe comprised most of the PAH content in this area followed by Flu and Pyr.

Concentrations of low molecular weight 2-4 ring PAHs were high predominated over while PAHs with high molecular (5-6 ring) weight are lower (Hu et al. 2010). Among the different aquatic systems, relatively high levels of PAHs were found in sediments from the southern wetland and the Yellow River estuary (Zhang 2008; Yuan et al. 2011). PAHs measured from Bird Island originating from oil nearby an oil pumping unit, indicating that the pollution is mainly caused by petroleum (Yuan et al. 2011). 
At this time, few studies have measured concentrations of POPs in biota from the YRD are available. No studies related to the OCPs and PAHs in biota in the YRD exist that we are aware of. Only two studies examined PCBs in biota. These studies examined accumulation of related to dioxin-like PCBs in plants (DL-PCBs) (Fan 2008; Fan et al. 2009). DL-PCBs are the most toxic group of PCB compounds. Though concentrations of DL-PCBs in environmental and biological matrices are generally low, they contribute much to the overall toxic value of PCBs. Fan et al., (2009) investigated interspecies variance of DL-PCBs in plants from the YRD. Concentrations of 12 DL-PCBs congeners were examined in five plant species (including Imperata cylindrical var. major, Phragmites australis (Cav.) Trin. Ex Steud, Suaeda Heteroptera, Tamarix chinensis Lout., Salix matsudana Koidz) and their associated soils. Concentrations of DL-PCBs in plants were $575.48-819.23 \mathrm{ng} / \mathrm{kg}$, and concentrations of DL-PCBs congeners in plants were 2.32-237.36 ng/kg. Plants in the sampling site of the YRD were not heavily polluted. DL-PCBs congener concentrations and ratios in plants greatly differed among species. The concentration of DL-PCBs in I. Cylindrical (575.48 ng/kg) was the lowest among the five specie. The other four species were not significantly different from each other $(p<0.05)$. Two plants belong to the same family among the five species. I. cylindrical and P. australis had the smallest variance among the five species for accumulating DL-PCBs. Interspecies variance of all plants examined increased with increasing log Koa of PCBs. Accumulation of DL-PCBs for annual plants was related to log Koa, while for perennial plants it was independent of log Koa.

There was no reported data related to the water POPs in the YRD.

Technical DDT and dicofol containing large amounts DDT-related compound impurities were the main sources of DDT pollution in China (Wang et al. 2005). Technical DDT is typically composed of $77.1 \% p, p^{\prime}$-DDT, $14.9 \% o, p^{\prime}$-DDT, $4 \% p, p^{\prime}$-DDE and some other trace impurities (Kannan et al. 1995).

Ratios of $o, p^{\prime}$-DDT/ $p, p^{\prime}$-DDT ranged from 0.2 to 0.3 in technical DDTs and from 1.3 to 9.3 or greater in dicofol, respectively (Qiu et al. 2005). The two main DDT-related compounds, $p$, $p^{\prime}$-DDE and $p, p^{\prime}$-DDD, account for $71.98 \%$ of the total in the YRD. $p, p$ '-DDT is largely degraded into $p$, $p$ '- DDE or $p$, $p$ '-DDD after years of microbial activity. In soil, DDT residues originated mainly from past agriculture usage. DDT in the environment is primarily transformed to the more stable metabolites DDD and DDE under anaerobic and aerobic conditions, 
respectively, by either biotic (microbial conversion) or abiotic processes (i.e. chemical breakdown, photodegradation) (Bosch et al. 2015). Experiments have shown that approximately 66\% of DDT applied to agricultural fields is transformed into DDE within one year (Cliath and Spencer 1972). A DDD/DDE ratio greater than 1 indicates that aerobic degradation is the main pathway of DDT loss. A ratio of less than 1 implies that the aerobic degradation is predominant (Wu et al. 2013). In general, a ratio of (DDE + DDD)/DDT greater than 0.5 indicates long-term biotransformation of DDT to DDE and DDD, while a ratio of less than 0.5 may indicate recent input of DDT (Hitch and Day 1992). Most DDE + DDD)/DDTs ratios in YRD soils samples were greater than 0.5, implying the existence of aged DDT in the study area. However, the (DDE + DDD)/DDTs ratios in a few soil samples were less than 0.5 , suggesting that there could be newer DDT inputs (Yuan et al. 2012). This newer input source of DDT was the pesticide 'dicofol' which is still widely used in the region to prevent the cotton bollworm. DDT was the raw material for industrial synthesis of dicofol, and because of this, often appears as an impurity in the dicofol product. Principal component analysis (PCA) and multiple regression analysis was used to identify the contaminated sources of DDTs (Xie et al. 2012). The analysis concluded that $86.4 \%$ of soil DDTs originates from past DDT usage, and $13.6 \%$ originates from dicofol application.

Technical $\mathrm{HCH}$ and lindane were two types of $\mathrm{HCH}$ products manufactured and used in China. Technical $\mathrm{HCH}$ contains about $55 \%$ to $80 \% \alpha-\mathrm{HCH}, 5 \%$ to $14 \% \beta-\mathrm{HCH}, 8 \%$ to $15 \%$ $\gamma-\mathrm{HCH}$ and minor proportions of other isomers while the major component of lindane is $\gamma-\mathrm{HCH}$ (>99\%) (Wang et al. 2009). Ratios of $\alpha / \gamma-\mathrm{HCH}$ have been used to identify the presence of $\mathrm{HCH}$ or lindane in environmental media in the YRD (Zhang, 2011). For example, the $\alpha / \gamma-\mathrm{HCH}$ ratio might be between 4 and 7 for the technical mixture, and nearly zero for lindane (Dai et al. 2011). Most sampling points in the Modern Course, Middle Area and Old Course of the Yellow River $\alpha / \gamma-\mathrm{HCH}$ ratios are greater than 7 (Zhang 2011). However, it is worth noting that the $\alpha / \gamma-\mathrm{HCH}$ ratio of two sampling points in the Modern Course and one sampling point in the Middle Area of the Yellow River was less than 1, indicating probable usage of lindane. The larger $\alpha / \gamma$ ratio might be due to the short half-life of $\gamma-\mathrm{HCH}$ in surface soil of only 2 months. It is possible that these are areas where the $\gamma$-HCH was degraded or bio-transformed completely. Additionally, $\mathrm{HCH}$ in the YRD could have originated from pesticide residues and long-range atmospheric transport of pesticide residues (Gao et al. 2008). 
Table 3 The correlation coefficients between the concentration of DL-PCBs and TOC, clay particles percent and sand particles percent

\begin{tabular}{cccc}
\hline & TOC & Clay content & Sand content \\
\hline Pearson's Coefficient & 0.457 & 0.648 & -0.472 \\
$\boldsymbol{P}$ & $<0.05$ & $<0.01$ & $<0.05$ \\
\hline
\end{tabular}

Production and usage of PCBs in the YRD mainly occurred before 1974. According to studies, the Modern Course of the YRD contains the highest levels of PCB contamination. Old Course contained more heavily chlorinated PCBs. Due to their high degree of chlorine substitution, heavily chlorinated PCBs exhibit poor migration and degradation ability. This property could explain why PCBs with heavy chlorination were more concentrated in the Old Course. Heavily chlorinated PCBs might have been deposited prior to the Yellow River diversion.Based on the rising trend of residual level of PCB 28 and PCB 52 in the Old course, Middle area and Modern course, these PCBs were deposited into the YRD after the Yellow River changed its course, even after PCBs went out of production. Other PCBs, such as PCB 153 and PCB 118 decreased in the Old course, Middle area and Modern course. It is possible that forbidden production of PCBs still played a limited role in PCBs degradation (Zhang 2011). Concentration of DL-PCBs had a slightly positive correlation with the TOC, a greatly significant positive correlation with clay content, and a significant negative correlation with sand content (Table 3). This result indicated that TOC, clay and sand contents in soil practical composition were the main influencing factors on the PCBs distribution (Liu 2008; Liu et al. 2010). Principle component analysis (PCA) was used to identify the contamination sources of PCBs (Liu et al. 2007). Principal component and multiple linear regression analysis suggested that soil PCBs most likely originate from the petrochemical industry $(77.1 \%)$, municipal solid waste disposal (16.5\%), local commercial PCB homologues usage (5.2\%), and long-range atmospheric deposition (1.2\%) (Xie et al. 2012).

Table 4 Literature values of selected molecular ratios of OCPs, PCBs and PAHs for various environmental sources

\begin{tabular}{l|l|l}
\hline Pollutant & Characteristic indicators & Values and sources \\
\hline
\end{tabular}




\begin{tabular}{|c|c|c|c|}
\hline DDT & $\begin{array}{l}m\left(p, p^{\prime}-\mathrm{DDE}+p, p^{\prime}-\mathrm{DDD}\right) / \\
m\left(p, p^{\prime}-\mathrm{DDT}\right)(\mathrm{Hitch} \text { and Day } 1992) \\
m\left(o, p^{\prime} \text {-DDT }\right) / \mathrm{m}\left(p, p^{\prime} \text {-DDT) (Qiu } e t\right. \\
\text { al. 2005) }\end{array}$ & $\begin{array}{l}>0.5 \text {, long-term } \\
\text { biotransformation of } \\
\text { DDT to DDE and } \\
\text { DDD } \\
0.2-0.3 \text {, technical } \\
\text { DDTs }\end{array}$ & $\begin{array}{l}<0.5 \text {, recent input of } \\
\text { DDT }\end{array}$ \\
\hline НCH & $\begin{array}{l}m(\alpha-\mathrm{HCH}) / m(\gamma-\mathrm{HCH})(\text { Dai et al. } \\
2011)\end{array}$ & 4-7, technical mixture & nearly zero for lindane \\
\hline РАH & $\begin{array}{l}m(\mathrm{Ph}) / m(\mathrm{An})(\mathrm{Baumard} \text { et al. } 1998) \\
m(\mathrm{Fl}) / m(\mathrm{Fl}+\mathrm{Pyr})(\text { Yunker } \text { et al. } 2002) \\
m(\mathrm{IP}) / m(\mathrm{IP}+\mathrm{BghiP})(\text { Yunker } \text { et al. } \\
2002) \\
m(\mathrm{Baa}) / m(\mathrm{Baa}+\mathrm{Chr})(\text { Yunker } \text { et al. } \\
2002) \\
m(\Sigma \mathrm{LMW}) / m(\Sigma \mathrm{HMW})^{\mathrm{a}}(\text { Fernandes } \\
\text { et al. } 1997)\end{array}$ & $\begin{array}{l}<10, \text { combustion } \\
\text { origin } \\
>0.4 \text {, combustion } \\
\text { origin } \\
>0.2 \text {, combustion } \\
\text { origin } \\
>0.35 \text {, combustion } \\
\text { origin } \\
<1, \text { combustion origin }\end{array}$ & $<0.2$, petroleum origin \\
\hline
\end{tabular}

a $\Sigma$ LMW = sum of Nap, Acy, Ace, Fl, Ph, and An;

$\Sigma$ HMW = sum of Flu, Pyr, Baa, Chr, BbF, BkF, BaP, IP, Dba, and BghiP.

The Shengli Oilfield, the second largest oilfield in China, is located in the YRD. Oil extraction and transportation leaks in the process can pollute the environment. C Petroleum coke and coal tar refining produce PAHs. Sites nearby oil pumping units had elevated levels of PAHs (Liu et al. 2008). If the concentration of PAHs in the soil is much higher than naturally occurring concentration, indicating that these soils are affected by human factors including chemical application, agricultural sewage sludge and accidental leakage, etc. Atmospheric wet and dry deposition plays a large role in PAH contamination (more than 90\%) (Edwards 1983; Wilcke 2007; Yang et al. 2007).

Various methods exist to assess the dominant origins of PAHs. One method commonly used method employs molecular indices based on the ratios of individual PAH levels in soil such as $\mathrm{Baa} /(\mathrm{Baa}+\mathrm{Chr})$ and $\mathrm{Fl} /(\mathrm{Pyr}+\mathrm{Fl})$ congener ratios (Yunker et al. 2002) (Table 4). According to ratio analysis $(\mathrm{Ph} / \mathrm{An}, \mathrm{Fl} / \mathrm{Fl}+\mathrm{Pyr}, \mathrm{IP} / \mathrm{IP}+\mathrm{BghiP}, \mathrm{Baa} /(\mathrm{Baa}+\mathrm{Chr})$, et al. $)$, PAHs contamination in the Yellow River Estuary showed a mixed PAH input pattern, including oil pollution, coal burning, 
and wood combustion (Liu 2008; Tao 2008). Six main sources were established, including: oil and asphalt refineries, coal combustion, wood combustion, gasoline engine exhaust, diesel engine exhaust and oil spills. In the published paper, a chemical mass balance (CMB) model was established and source profiles were collected from the literature, effective and popular method to identify the origins of PAHs (US EPA 2004; Kim et al. 2013; Manoli et al. 2016). Coal and wood combustion are the two major sources of PAHs in the Yellow river estuarine area, whose relative contribution were $30.5 \%$ and $27.7 \%$. Gasoline engine exhaust accounted for $17.49 \%$, diesel engine exhaust, $12.53 \%$, oil spills, $8.04 \%$, and oil and asphalt refineries 3.73\% (Liu 2008). The result of CMB model was consistent with that of factor analysis - multiple regression analysis (Liu et al. 2008). The factor analysis - multiple regression analysis indicated PAH contaminations in Yellow River Estuary area originated from coal and wood combustion, vehicles emission, oil spill, oil and asphalt refinery, which accounted for $41.89 \%, 27.43 \%, 10.76 \%$, and $19.92 \%$ of PAHs respectively. Additionally, the PAHs have been compared with the individual PAHs concentrations, TOC content and particle size distribution. TOC of surface sediments in the Yellow River estuarine sediment were within the range of $0.86-2.85 \%$, and the surface sediment was mainly comprised of silt. Multiple linear regressions showed that Pyr possessed the best linear relationship with the PAHs. Correlations of PAHs with particle size distribution and TOC were very weak which might be relatively low concentrations of PAHs in soils (Tao, 2008).

According to Chinese Environmental Quality Standard for Soils (GB15618-1995), soil can be classified as no DDTs pollution (< $50 \mathrm{ng} / \mathrm{g})$, low DDTs pollution $(50-500 \mathrm{ng} / \mathrm{g})$, moderate DDTs pollution $(500-1000 \mathrm{ng} / \mathrm{g})$, and severe DDTs pollution $(<1000 \mathrm{ng} / \mathrm{g})$. Concentrations of $\sum \mathrm{DDT}$ surveyed in the YRD in most samples were lower than the first grade $(50 \mathrm{ng} / \mathrm{g})$, except samples in the Bincheng district in Binzhou City (Chen et al. 2011). In the Bincheng district, soil concentrations in eight samples (five samples from the rural area, two samples from the suburban area and one sample from urban area) reached the moderate pollution level, and three samples (two samples from the rural area and one sample from the suburban area) had severe pollution (Xie et al. 2012). DDT pollution levels in the rural area were significantly higher than in suburban and urban areas. Dutch soil guidelines and Canadian soil quality guidelines were also adopted to assess soil quality. The mean soil DDTs concentration in the YRD was far higher than the target value $(10 \mathrm{ng} / \mathrm{g})$, but lower than the intervention value $(4000 \mathrm{ng} / \mathrm{g})$ in Dutch soil guidelines 
(VROM 2000). According to Canadian Soil Quality Guidelines for the Protection of Environment and Human Health, concentrations of DDTs in all soil samples in urban area were lower than the soil guideline value of $700 \mathrm{ng} / \mathrm{g}$ for residential and parkland soils. DDTs concentrations in $8.6 \%$ and $6.5 \%$ of soil samples from rural and suburban areas were higher than the soil guideline value of $700 \mathrm{ng} / \mathrm{g}$ for agricultural soils, respectively (CCME 2007). For soil HCHs, the concentrations of $\sum \mathrm{HCHs}$ in all reported samples were lower than the first grade $(50 \mathrm{ng} / \mathrm{g})$. Thus, pollution levels of soil HCHs and DDTs in YRD were relatively mild. Two widely used sediment quality guidelines, i.e. the effects range-low value (ERL) and effects range-median value (ERM) guidelines (Long et al. 1995), as well as the threshold effects level (TEL) and probable effects level (PEL) guidelines (CCME 2002) were applied to evaluate the possible eco-toxicological risks of OCPs in the study area (Table 3). For DDTs, although levels did not exceed than ERM (46.1 ng/g) and PEL values $(51.7 \mathrm{ng} / \mathrm{g})$, partial sites in the study area were higher than ERL $(1.58 \mathrm{ng} / \mathrm{g})$ and TEL values (3.89 $\mathrm{ng} / \mathrm{g}$ ), suggesting that the exposure of DDTs may cause ecological risk on more sensitive organisms, such as the neighboring benthic organisms. 
Table 5 Popular standards summaries for OCPs, PCBs and PAHs in China and abroad in various

\section{environmental media}

\begin{tabular}{|c|c|c|c|c|c|c|}
\hline Pollutant & Soil (ng/g) & \multicolumn{3}{|c|}{ Sediment (ng/g) } & Water (ng/L) & Organism (ng/g) \\
\hline \multirow[t]{8}{*}{ DDTs } & National Environmental Quality & \multirow{3}{*}{\multicolumn{3}{|c|}{$\begin{array}{l}\text { Canadian Sediment Quality Guidelines } \\
\text { for the protection of aquatic life } \\
\text { (CCME 2002) }\end{array}$}} & Environmental Quality & \\
\hline & Standards for Soils of China & & & & Standards for water of & \\
\hline & (GB15618- 1995) (MEP 1997) & & & & China (MEP 2002) & \\
\hline & $\mathrm{I}<50^{\mathrm{a}}$ & \multirow{5}{*}{$\begin{array}{l}\text { DDE } \\
\text { DDD } \\
\text { DDT } \\
\text { DDTs }\end{array}$} & $\mathrm{ERL}^{\mathrm{b}}$ & ERM & & \multirow{5}{*}{-} \\
\hline & II $<500$ & & 2.2 & 27 & DDTs, 1000 & \\
\hline & III $<1000$ & & 2 & 20 & & \\
\hline & & & & & & \\
\hline & & & 1.58 & 46.1 & & \\
\hline \multirow[t]{6}{*}{ HCHs } & National Environmental Quality & \multirow{3}{*}{\multicolumn{3}{|c|}{$\begin{array}{l}\text { Canadian Sediment Quality Guidelines } \\
\text { for the protection of aquatic life } \\
\text { (CCME 2002) }\end{array}$}} & Environmental Quality & \\
\hline & Standards for Soils of China & & & & Standards for water of & \\
\hline & (GB15618- 1995) (MEP 1997) & & & & China (MEP 2002) & \\
\hline & I $<50$ & \multirow{3}{*}{$\gamma-\mathrm{HCH}$} & \multirow{3}{*}{$\begin{array}{l}\text { ERL } \\
0.32\end{array}$} & \multirow{3}{*}{$\begin{array}{l}\text { ERM } \\
0.99\end{array}$} & & \\
\hline & II $<500$ & & & & $\gamma$-HCH, 2000 & - \\
\hline & III $<1000$ & & & & & \\
\hline \multirow[t]{7}{*}{ PCBs } & Canadian Soil Quality Guidelines & \multirow{3}{*}{\multicolumn{3}{|c|}{$\begin{array}{l}\text { Canadian Sediment Quality Guidelines } \\
\text { for the protection of aquatic life } \\
\text { (CCME 2002) }\end{array}$}} & Environmental Quality & Maximum levels of \\
\hline & for the Protection of Environmental & & & & Standards for water of & contaminants in foods \\
\hline & and Human Health (CCME 2007) & & & & China (MEP 2002) & (MHP 2005) \\
\hline & Industry land, 50000 & \multirow{4}{*}{$\begin{array}{l}\text { Freshwater } \\
\text { sediment } \\
\text { Marine } \\
\text { sediment }\end{array}$} & ISQG $^{\mathrm{c}}$ & $\mathrm{PEL}^{\mathrm{d}}$ & \multirow[t]{4}{*}{$\mathrm{PCBs}, 8$} & \multirow[t]{4}{*}{ PCBs 2000} \\
\hline & Leisure land, 5000 & & 34.1 & 277 & & \\
\hline & & & & & & \\
\hline & Agriculture land, 500 & & 21.5 & 189 & & \\
\hline \multirow[t]{6}{*}{ PAHs } & Classification of Soil Contamination & \multirow{3}{*}{\multicolumn{3}{|c|}{$\begin{array}{l}\text { Classification of Sediment } \\
\text { Contamination (Baumard et al. 1998) }\end{array}$}} & Environmental Quality & Maximum levels of \\
\hline & (Maliszewska-Kordybach 1996) & & & & Standards for water of & contaminants in foods \\
\hline & & & & & China (MEP 2002) & (MHP 2005) \\
\hline & I $<200$ & \multirow{3}{*}{\multicolumn{3}{|c|}{$\begin{array}{l}\text { I }<100 \\
\text { II }<1000 \\
\text { III }<5000\end{array}$}} & Bap 2.8 & Bap 5 for cereals; \\
\hline & II $<600$ & & & & & 10 for vegetable oil \\
\hline & III $<1000$ & & & & & \\
\hline
\end{tabular}

a, I: non-contaminated soil, II: weakly contaminated soil; III: contaminated soil;

b, ERL: the effects range-low value;

c, ISQG: the interim sediment quality guideline;

d, PEL: the probable effect level. 
In China, most PCB-containing equipment was stored at special disposal sites when they were taken out of use. The China State Environmental Protection Administration (SEPA) reported that directly polluted soils in some sealed storage locations reached as high as $4.54 * 10^{6}$ ng/g, with levels in surrounding lands and farmlands having as much as $2930 \mathrm{ng} / \mathrm{g}$ (SEPA 2003). Along China's southeast coast, where some residents were illegally trading in or dismantling PCB-containing equipment, PCB concentrations have been found as high as $788 \mathrm{ng} / \mathrm{g}$ (Chu et al. 1995). Compared to the Canadian Soil Quality Guidelines for the Protection of Environmental and Human Health (CCME 2007), all of the reported soil PCB values were lower than the standards for leisure land; however some reported PCB values were greater than the standards for agricultural land. Compared to the Union of Soviet Socialist Republics (USSR) Ministry of Health's allowable level of $60 \mathrm{ng} / \mathrm{g}$ for PCBs in ambient soil, all areas in the YRD had relatively largerPCB contamination levels on average (Bi et al. 2002). Agricultural soils sampled in suburban Beijing reported concentration levels of only $0.18 \mathrm{ng} / \mathrm{g}$ (Chu et al. 1995). Soils sampled from Shenyang, a major industrial city in north China's Liaoning Province, had PCB levels of 6.4-15.2 ng/g (Jing et al. 1992). While the pollution situation seems to be in control, the threat posed by seriously polluted point sources is concerning and should be a priority when assessing the risks identified by current data (Xing et al. 2005) .

Risk assessment for PAHs in sediments has been well documented in the literature (Zhang et al., 2012), and information is available on the qualitative risk assessment for PAHs. Natural background levels of soil PAHs generally range from 1 to $10 \mathrm{ng} / \mathrm{g}$, and are mainly derived from the decomposition of plants and natural fires (Yang et al. 2007). Based on the reported results in the YRD, there were no soils with PAHs concentrationless than $10 \mathrm{ng} / \mathrm{g}$. All of the soil tested has been subject to human influence, which is not surprising given the ubiquitous nature of PAHs. In China, concentration of the 16 PAHs in surface soils ranged from not detected to $151,600 \mathrm{ng} / \mathrm{g}$, with the average of $3654.97 \mathrm{ng} / \mathrm{g}$, the coefficient of variation was 4.44 , with a median value of $580 \mathrm{ng} / \mathrm{g}$. Due to the lack of PAH evaluation standards in China, concentrations of the 16 PAHs were also compared with the criteria put forward by Maliszewska-Kordybach (1996). Soil PAH contamination ranges were divided into four categories: unpolluted ( $<200 \mathrm{ng} / \mathrm{g})$, weakly polluted (200-600 ng/g), moderately polluted (600-1000 ng/g), and severely polluted (>1000 ng/g). The concentrations of $\sum$ PAHs in most samples were lower than the first grade (200ng/g), except 
samples in the Bincheng district in the Binzhou City (Chen et al. 2011; Xie et al. 2012). In the Bincheng district in Binzhou City, all suburban soil, $94.3 \%$ of the rural soil, and $43.8 \%$ of the urban soil PAHs fell in the weakly polluted category. $37.5 \%$ and $18.7 \%$ urban sample concentrations fell in the moderately polluted category and severely polluted category, respectively (Xie et al. 2012). Therefore, it was determined that soil in this area has moderate PAHs pollution. According to Baumard et al. (1998), levels of sediment pollution by PAHs can be classified as low (10-100 ng/g), moderate (100-1000 ng/g), high (1000-5000 ng/g), and very high (5000 ng/g). According to these criteria, the levels of PAH in sediments samples could be classified from low (northern YRD) to moderate (other parts of YRD). Under the Canadian criteria of ERL (4022 ng/g) and ERM (44792 ng/g) (Long et al. 1995), all of the PAHs were lower than the ERL. Also, PAHs concentrations were at lower level in Yellow river estuarine compared with relevant areas worldwide in the published reports (Oliva et al. 2015). Compared soil PAHs in the YRD region with in some developed regions in China, concentrations were much lower than that in Beijing (suburban topsoil, 16 - 3884ng/g) (Ma et al. 2005), Hangzhou (59.71 - $615.8 \mathrm{ng} / \mathrm{g}$ ) (Chen et al. 2004), and Hong Kong (urban soil 16 PAHs was 42.9 - $410 \mathrm{ng} / \mathrm{g}$ ) (Zhang et al. 2006), but much larger than uncontaminated soil PAHs levels required by the Dutch government (20.0 - 50.0 ng/g) (Van Brummelen et al. 1996). Even so, soil PAHs contamination from petroleum deserves more attention, particularly near petrochemical production sites, In addition, PAHs from petroleum are more labile and can react with other pollutants to form more toxic derivates. Although soil PAHs was generally in good condition compared to some other regions, the abnormally higher levels of soil PAHs still need vigilance (Cao et al. 2012).

A comprehensive assessment of the state of the POPs and spatial patterns in multiple environmental media in the YRD were conducted on a regional scale with the literature available. Levels of DDTs, PAHs and PCBs in soil and sediment samples were sufficient to cause potential ecological risk, but no negative effect was derived from the burden of HCHs. Spatial distribution of OCPs significantly increase along urban- rural gradient, while PCBs and PAHs showed opposite, which indicated a significant influence of agricultural, urban industrial practices, water and sediment transport and atmospheric deposition. Primary sources of DDTs, HCHs and PCBs mainly originated from the historical usage, new input of pesticide, and the petrochemical industry. PAH contamination was derived primarily from oil pollution and combustion of fossil 
fuels. At this point in time, only qualitative ecological risk assessment of POPs is feasible due to lack of monitoring information and regulatory guidelines. Additionally, assessment of environmental fate focusing on atmospheric deposition, air-soil/water exchange, and riverine transport in the YRD was not available. Quantitative monitoring and transfer mechanism research programs would be useful to fill in the existing data gaps.

\section{Acknowledgments}

This study was supported by the Program for "Bingwei" Excellent Talents in Institute of Geographic Sciences and Natural Resources Research, CAS, National Science Foundation (No. 41201514 and 41271047) and Open Foundation of Key Laboratory of Poyang Lake Environment and Resource Utilization (Nanchang University), Ministry of Education.

\section{Conflicts of Interest}

The authors declare no conflict of interest.

\section{References}

Baumard, P., et al. 1998. Origin and bioavailability of PAHs in the Mediterranean sea from mussel and sediment records. Estuarine Coastal and Shelf Science 47(1): 77-90.

Bi, X. H., et al. 2002. Movement and retention of polychlorinated biphenyls in a paddy field of WenTai area in China. Agriculture Ecosystems \& Environment 89(3): 241-252.

Bosch, C., et al. 2015. Enantiomeric fraction and isomeric composition to assess sources of DDT residues in soils. Chemosphere 138: 40-46.

Cai, Q., et al. 2008. The status of soil contamination by semivolatile organic chemicals (SVOCs) in China: A review. Science of the Total Environment 389(2-3): 209-224.

Cao, Y., et al. 2012. Patterns of PAHs concentrations and components in surface soils of main areas in China. Acta Scientiae Circumstante 32(01): 197-203

CCME (2002). Canadian Council of Ministers of the Environment. Canadian Sediment Quality Guidelines for the Protection of Aquatic Life, Environment Canada. Ottawa, Canada.

CCME (2007). Canadian Council of Ministers of the Environment, Canadian Soil Quality Guidelines for the Protection of Environmental and Human Health. Winnipeg, Canada.

Cenci, R. M., et al. 2004. Concentration and fate of trace metals in Mekong River Delta. Science of the Total Environment 332(1-3): 167-182.

Chen, A., et al. 2011. Distribution characteristics and risk analysis of DDTs in soils of the Yellow River Delta. Shandong Forestry Science And Technology 195(04): 1-3.

Chen, B. L., et al. 2004. Distributions of polycyclic aromatic hydrocarbons in surface waters, sediments and soils of Hangzhou City, China. Water Research 38(16): 3558-3568. 
China SEPA (2003). Building the capacity of the People's Republic of China to implement the Stockholm convention on POPs and develop a National implementation plan. GEF Project Brief (GF/CPR/02/010).

Chu, S., et al. 1995. Polychlorinated biphenyl congener residues in sediment and soil from pollution area. China Environ. Sci 15(3): 199-203.

Cliath, M. M., et al. 1972. Dissipation of Pesticides from Soil by Volatilization of Degradation Products .1. Lindane and Ddt. Environmental Science \& Technology 6(10): 910-914.

Da, C. N., et al. 2014. Sources and risk assessment of organochlorine pesticides in surface soils from the Nature Reserve of the Yellow River Delta, China. Soil Science Society of America Journal 78(3): 779-786.

Da, C. N., et al. 2014. Analysis of HCHs and DDTs in a sediment core from the Old Yellow River Estuary, China. Ecotoxicology and Environmental Safety 100: 171-177.

Dai, G., et al. 2011. Distribution of organochlorine pesticides (OCPs) and poly chlorinated biphenyls (PCBs) in surface water and sediments from Baiyangdian Lake in North China. Journal of Environmental Sciences 23(10): 1640-1649.

Edwards, N. T. 1983. Polycyclic Aromatic Hydrocarbons (PAHs) in the terrestrial environment - a Review. Journal of Environmental Quality 12(4): 427-441.

Fan, G. L. 2008. Sources, accumulation and distribution of dioxin-like PCBs in the typical plants from Yellow River Delta. PhD Shandong University.

Fan, G. L., et al. 2009. Interspecies variability of Dioxin-like PCBs accumulation in five plants from the modern Yellow River delta. Journal of Hazardous Materials 163(2-3): 967-972.

Fernandes, M. B., et al. 1997. Polyaromatic hydrocarbon (PAH) distributions in the Seine River and its estuary. Marine Pollution Bulletin 34(11): 857-867.

Gao, F., et al. 2008. Occurrence and ordination of dichlorodiphenyltrichloroethane and hexachlorocyclohexane in agricultural soils from Guangzhou, China. Archives of Environmental Contamination and Toxicology 54(2): 155-166.

Gong, Z. M., et al. 2004. Residues of Hexachlorocyclohexane Isomers and Their Distribution Characteristics in Soils in the Tianjin Area, China. Archives of Environmental Contamination and Toxicology 46(4): 432-437.

Hitch, R. K., et al. 1992. Unusual persistence of DDT in some western USA soils. Bulletin of Environmental Contamination and Toxicology 48(2): 259-264.

Hu, J. Y., et al. 2005. Occurrence of trace organic contaminants in Bohai Bay and its adjacent Nanpaiwu River, North China. Marine Chemistry 95(1-2): 1-13.

Hu, N., et al. 2010. Distribution and Origin of PAHs in the Surface Sediments of the Yellow River Estuary and It's Adjacent Areas. Bulletin of Mineralogy, Petrology and Geochemistry 29(2): $157-163$

IPCS 2000. International Programme on Chemical Safety. The WHO recommended classification of pesticides by hazard and guidelines to classification.

Jing, Z., et al. 1992. The study of polychlorinated biphenyls for their loss, contamination and protection strategy. Huan jing ke xue cong kan 13: 1-28.

Kannan, K., et al. 1995. Geographical distribution and accumulation features of organochlorine residues in fish in tropical Asia and oceania. Environmental Science \& Technology 29(10): 2673-2683.

Keita-Ouane, F., et al. 2001. The IOMC organisations: a source of chemical safety information. 
Toxicology 157(1-2): 111-119.

Kim, I. S., et al. 2013. Impact of polycyclic aromatic hydrocarbon (PAH) emissions from North Korea to the air quality in the Seoul Metropolitan Area, South Korea. Atmospheric Environment 70: 159-165.

Li, Q. L., et al. 2006. Evaluating the fate of p,p'-DDT in Tianjin, China using a non-steady-state multimedia fugacity model. Ecotoxicology and Environmental Safety 63(2): 196-203.

Liu, A., et al. 2009. Ecological risk assessment of PAHs in surface sediments from the Yellow River estuary. Ecology and Environment 18(2): 441-446.

Liu, J., et al. 2007. Source Apportionment of Dioxin-like Polychlorinated Biphenyls in Soil of the Modern Yellow River delta. Environmental Science 28(2): 2771-2776.

Liu, J., et al. 2010. Influences of soil characteristics on the PCBs distribution in soil of the modern Yellow River delta. Ecology and Environmental Sciences 19(01): 86-91.

Liu, Z. 2008. Surface apportionment of PAHs in sediments from the Yellow River estuary and Laizhou bay Master Degree, Ocean University of China.

Liu, Z., et al. 2008. Source apportionment of PAHs in estuarine sediment from the Yellow River. Research of Envionmental Sciences 21(5): 79-84.

Long, E. R., et al. 1995. Incidence of adverse biological effects within ranges of chemical concentrations in marine and estuarine sediments. Environmental Management 19(1): 81-97.

Ma, L. L., et al. 2005. Polycyclic aromatic hydrocarbons in the surface soils from outskirts of Beijing, China. Chemosphere 58(10): 1355-1363.

Maliszewska-Kordybach, B. 1996. Polycyclic aromatic hydrocarbons in agricultural soils in Poland: Preliminary proposals for criteria to evaluate the level of soil contamination. Applied Geochemistry 11(1-2): 121-127.

Manoli, E., et al. 2016. Polycyclic aromatic hydrocarbons (PAHs) at traffic and urban background sites of northern Greece: source apportionment of ambient PAH levels and PAH-induced lung cancer risk. Environmental Science and Pollution Research 23(4): 3556-3568.

MEP (1997). Ministry of Environmental Protection of the People's Republic of China. Environmental quality standard for soils (GB15618-1995). Beijing.

MEP (2002). Ministry of Environmental Protection of the People's Republic of China. Environmental quality standards for surface water (GB3838-2002). Beijing.

MHP (2005). Ministry of Health of the People's Republic of China. Maximum levels of contaminants in foods (GB2762-2005). Beijing.

Oliva, A., et al. 2015. Distribution, sources, and potential ecotoxicological risk of Polycyclic Aromatic Hydrocarbons in surface sediments from Bahía Blanca estuary, Argentina. Archives of Environmental Contamination and Toxicology 69(2): 163-172.

Peterson, P. J., et al. 2010. Indicators as a tool for the evaluation of effective national implementation of the Globally Harmonized System of Classification and Labelling of Chemicals (GHS). J Environ Manage 91(5): 1202-1208.

Qiu, X. H., et al. 2005. Contribution of dicofol to the current DDT pollution in China. Environmental Science \& Technology 39(12): 4385-4390.

Sudaryanto, A., et al. 2011. Assessment of persistent organic pollutants in sediments from Lower Mekong River Basin. Chemosphere 82(5): 679-686.

Sun, J. H., et al. 2008. Correlation analysis and risk assessment of organochlorine pesticides in surface sediments from the Yellow River. Acta Scientiae Circumstantiae 28(2): 342-348. 
Tao, S., et al. 2007. Spatial and temporal variations and possible sources of dichlorodiphenyltrichloroethane (DDT) and its metabolites in rivers in Tianjin, China. Chemosphere 68(1): 10-16.

Tao, S., et al. 2006. Modeling the dynamic changes in concentrations of $\gamma$-hexachlorocyclohexane $(\gamma-\mathrm{HCH})$ in Tianjin region from 1953 to 2020. Environmental Pollution 139(1): 183-193.

Tao, X. 2008. Study on the organic pollution status and source identification of PAHs in soils of the Yellow River Delta region Master Degree, Ocean University of China.

UNEP 2003. Regionally based assessment of persistent toxic substances. Global Report. http://www.chem.unep.ch/pts/ [accessed 2 April 2007].

US EPA (2004). Environmental Protection Agency, EPA-CMB8.2 Users Manual. EPA Publication No. EPA-452/R-04-011, Research Triangle Park, NC, USA.

Van Brummelen, T. C., et al. 1996. Enrichment of polycyclic aromatic hydrocarbons in forest soils near a blast furnace plant. Chemosphere 32(2): 293-314.

VROM (2000). Circular on Target Values and Intervention Values for Soil Remediation. Ministry of the Housing, Spatial Planning and Environment, Hague, Holand.

Wang, G., et al. 2009. Regional differences and sources of organochlorine pesticides in soils surrounding chemical industrial parks. Environmental Monitoring and Assessment 152(1-4): 259-269.

Wang, T., et al. 2005. Contamination of persistent organic pollutants (POPs) and relevant management in China. Environment International 31(6): 813-821.

Wilcke, W. 2007. Global patterns of polycyclic aromatic hydrocarbons (PAHs) in soil. Geoderma 141(3-4): 157-166.

Wu, C., et al. 2013. Risks from sediments contaminated with organochlorine pesticides in Hangzhou, China. Chemosphere 90(9): 2341-2346.

Xie, W., et al. 2012. County-scale distribution of polycyclic aromatic hydrocarbons in topsoil of the Yellow River Delta Region. Journal of Environmental Science and Health Part a-Toxic/Hazardous Substances \& Environmental Engineering 47(10): 1419-1427.

Xie, W., et al. 2012. Topsoil dichlorodiphenyltrichloroethane and polychlorinated biphenyl concentrations and sources along an urban-rural gradient in the Yellow River Delta. J Environ Sci-China 24(9): 1655-1661.

Xing, X., et al. 2005. A spatial temporal assessment of pollution from PCBs in China. Chemosphere 60(6): 731-739.

Yang, G., et al. 2007. Source and distribution characteristics of polycyclic aromatic hydrocarbons in agricultural soils in the Pearl River Delta. ENvironment Science 28(10): 2350-2354.

Yang, Z., et al. 2009. Distribution and speciation of heavy metals in sediments from the mainstream, tributaries, and lakes of the Yangtze River catchment of Wuhan, China. Journal of Hazardous Materials 166(2-3): 1186-1194.

Yuan, H. M., et al. 2011. Distribution of polycyclic aromatic hydrocarbons in the surface soil of southern wetland of the Yellow River Delta and ecological risk assessment. Marine Geology Frontiers 27(02): 24-28.

Yuan, H. M., et al. 2012. Dstribution of organochlorine pesticides in surface soil of the Yellow River delta and ecological risk assessment. Marine Geology Frontiers 28(11): 43-46.

Yuan, H. M., et al. 2008. Polycyclic aromatic hydrocarbons ( pahs) exposure and their source analysis in the northern wetland of the Yellow River Delta. Marine Geology \& Quaternary 
Geology(06): 57-62.

Yunker, M. B., et al. 2002. PAHs in the Fraser River basin: a critical appraisal of PAH ratios as indicators of PAH source and composition. Organic Geochemistry 33(4): 489-515.

Zhang, H. B., et al. 2006. Distributions and concentrations of PAHs in Hong Kong soils. Environmental Pollution 141(1): 107-114.

Zhang, J. 2008. Distributions and sources of hydrocarbons in the Yellow River and its Estuary. PhD, Ocean University of China.

Zhang, K. 2011. Occurrence and risk of persistent toxic substances in Wetland soil from the modern Yellow River Delta. Master degree, Dalian university of technology. 